\title{
De Juana Paula Manso a Juana Manuela Gorriti:
}

cozinha e culinária nos escritos de duas letradas argentinas do século XIX

\section{From Juana Paula Manso to Juana Manuela Gorriti: \\ kitchen and cooking in the writings of two $19^{\text {th }}$ century Argentine literate women}

Juana Paula Manso (1819-1875) e Juana Manuela Corriti (1816-1892) foram duas letradas argentinas que, além de publicar em jornais de Buenos Aires e de outras cidades americanas, foram autoras de relatos de viagens, obras históricas, contos e romances, tendo participado do espaço público letrado bonaerense de forma ativa durante a segunda metade do século XIX. A partir de suas atividades, Manso e Gorriti refletiam sobre os temas que mais Ihes interessavam: o papel da mulher na sociedade, a educação e a política eram questões que constantemente faziam parte de suas preocupações e de suas narrativas.

Segundo estudiosas das letradas, como Graciela Batticuore e Marina L. Guidotti, seus textos demonstram que o espaço feminino não deveria restringir-se somente ao âmbito doméstico. A cozinha e a culinária, assim, acabaram fazendo parte de suas reflexões. Nesta comunicação pretendo compreender como esse lugar e esse fazer foram pensados e representados pelas duas mulheres públicas aqui estudadas em seus escritos. Para isso, serão analisadas fontes históricas como o Jornal das Senhoras, editado por Juana Paula Manso em 1852, e Cocina Eclética, um livro de receitas publicado por Juana Manuela Corriti em 1890. Há que se considerar que Manso escreveu palavras como as seguintes no Jornal das Senhoras (1852): "La emancipación moral de la mujer es considerada por la vulgaridad como el apocalipsis del siglo. Los unos corren al diccionario y exclaman: ¡Ya no hay autoridad paterna! ¡Adiós despotismo marital! ¡Emancipar a la mujer! ¡Cómo! Pues ese trasto de salón (o de cocina), esa máquina procreativa, ese cero dorado, ese frívolo juguete, esa muñeca de las modas, ¿será un ser racional?". No mesmo sentido, segundo Craciela Batticuore em La Mujer Romántica: Lectoras, Autoras y Escritores en la Argentina (2005), "as heroínas dos relatos de Corriti dizem não ao ideal da família e ao lar", já que, em sua produção literária, o "mundo de fora" e "os caminhos e a ânsia de sair" é que regiam o universo de expectativas que forjavam o imaginário das personagens femininas,

Juana Manuela Gorriti, no entanto, acabou por produzir, no fim de sua vida, Cocina Eclética. Especialmente sobre essa obra, buscarei respostas para as seguintes questões: o que poderia ter motivado a letrada a produzir uma obra abordando exatamente e estritamente os fazeres culinários? Por que a escritora pensou ser preciso registrar e publicar um receituário? O que exatamente contém essa obra? A quem esse escrito era dirigido? O que a sua "culinária de papel" - como Laura G. Comes e Lívia Barbosa entendem os materiais impressos relativos às cozinhas e à culinária em artigo por elas publicado em 2005 - queria expressar, especialmente no que diz respeito à relação das mulheres com a cozinha (enquanto espaço doméstico) e com a comida nela produzida? Minha 
comunicação, assim, contribuirá para as discussões sobre a história das mulheres, os estudos de gênero e suas relações com a história da alimentação.

Palavras-chave: Juana Paula Manso; Juana Manuela Corriti; cozinha; culinária; gênero.

Keywords: Juana Paula Manso; ]uana Manuela Corriti; kitchen; culinary; gender.

1 Doutora em História na Universidade Federal do Rio Grande do Sul, professora colaboradora do Programa de PósGraduação em História e do curso de Graduação Tecnológica em Gastronomia da Universidade do Vale do Rio dos Sinos e na Especialização em História da Alimentação e Patrimônio Cultural da Universidade de Santa Cruz. 